\title{
THE ANALYSIS OF FORMULA IN THE LEGEND OF JAPANESE SAMURAI RUROUNI KENSHIN AND MIYAMOTO MUSHASI: POPULAR LITERARY APRROACH
}

\author{
Tomi Arianto ${ }^{1}$. Universitas Putera Batam, Batam- Kepri \\ tomy2088.ta@gmail.com \\ Ambalegin ${ }^{2}$.Universitas Putera Batam, Batam- Kepri \\ abhi140475@gmail.com
}

\begin{abstract}
ASBTRAK
Penelitian ini mengkaji tentang formulasi pada kisah heroic legendaris serta popular di Jepang tentang cerita Rurouni Kenshin atau sering disebut sebagai Samurai X dan Miyamoto Mushashi atau disebut Samurai I. Kedua cerita tersebut kemudian disadur kedalam layar kaca dan mendapat respon positif bahkan masuk dalam star 7 di Box Office dan imdb. Jelas kedua cerita tersebut melonjak kembali sebagai karya popular dan layak dikaji dengan menggunakan pendekatan Sastra Populer. Untuk menguji hipotesis tersebut, peneliti menggunakan teori Cawelty dengan pendekatan formula Sastra Populer. Dengan menggunakan konsep Cawelty, penelitian ini mengkaji tentang formula yang digunakan dalam kedua cerita legenda jepang Rurouni Kenshin dan Miyamoto Mushashi terkait persamaan dan perbedaan serta faktor-faktor yang menyebabkan keduanya menjadi popular sesuai nilai dan selera penonton. Hasil penelitian menunjukkan bahwa kedua legenda aksi tersebut secara umum mempunyai formula cerita action yang sama sebagaimana rumusan cawelty, struktur cerita/narasi, dan kesamaan motif tindakan. Perbedaan dari kedua ceritanya terutama terletak pada cara narator menyajikan mitologi dan metafor. Formula merupakan salah satu faktor utama yang membuat suatu cerita disukai dan mendapat respon positif di pasaran, termasuk juga konsistensi, orisinalitas, kemampuan menarik keajaiban, tempat dan gaya dalam penyajian cerita.
\end{abstract}

Kata Kunci: Sastra Populer, Formula, Arketipe, Miyamoto Musashi, dan Rurouni Kenshin.

\section{INTRODUCTION}

The term popular literature is derived from the term mass culture contained in the categorization of culture into an elite / supreme culture or high culture and mass culture. This is partly confirmed by Clifford Geertz (in Ibrahim, 1997) in the article "Lifestyle Ecstasy: Culture in the Indonesian Commodity Society". Victor E. Neuburg (1977) in Popular Literature: A History and Guide, which writes based on the development of literature popular in England in the 19th century, popular literature was defined as what the unsophisticated reader has chosen for pleasure. Thus, according to him popular literature was the reading of ordinary readers for entertainment. Umar Kayam defined popular literature from its readers and the distribution process. Popular literature based on Kayam (1981) was interpreted as literature written for popular tastes and then sold as merchandise. Faruk \& Suminto (1997) associated literature with popular people but in a broader sense. According to them, popular literature is literature that is related to many people, with most citizens, 
and even whole. From these various definitions, popular literature can be interpreted as literature produced and created with the aim of fulfilling the tastes of many people or masses that function as entertainment, and distributed as commodity industry products as well as commercial. Popular literature itself is categorized as written literature and oral literature.

Aesthetically and the value of serious literature has a higher meaning than "popular literature". In the world lane literary works are hard to find, or even a work unit that is 100 percent shows its originality. There are always similarities with previous works. Many aspects can be used to assess the originality of literature. First, it is seen from one of the elements that builds related literary works; theme, background, character, plot (if novel); bait, array, diction, or figurative language(if poetry) or figures, themes, backgrounds, lines, forms of dialogue or guidance for staging (if drama). Second, judging from the way it is presented; how the author tells his story (novel), his image (poetry) or the guidance dialogue for the drama (drama).

Criteria for complexity are related to the burden carried by each element. Considering that literary works cannot be separated from the message or theme that they carry out, it is not uncommon for demands to carry out solutions to the theme concerned. Thus, the method of resolution is not easy, not artificial, and appears not limited to what appears on the surface, if the solution is carried out easily, it will enter into what is known as popular literature(Cawelty, 1976).

The story of Rurouni Keshin aka Samurai $\mathrm{X}$ and Miyamoto Musashi at the beginning of its emergence is a collection of serial films aired on television. The development both of the stories due to the large audience interest, the stories was finally made in the form of a movie and gained considerable appreciation among the audience. Rurouni Kenshin aka Samurai X released in 2012 directed by Keishi Omotomo which was adapted from a phenomenal serial comic in the 1990s by Nobuhiro Watsuki. This film is the ninth best film in Japan in the Box Office record that is able to reap profits of up to US $\$ 61,700,000$ by distributing it throughout the world (Wikipedia 2014). Caused of the high appreciation of the community for this movie, Keishi Otomo resumed the series titled Rurouni Kenshin: Kyoto Inferno which was released at the end of 2014.Whereas the second story titled Miyamoto Musashi, also called Samurai I was directed by Hiroshi Inagaki which was released in 1956. This story was adapted from a novel written by Eiji Yoshikawa in the 1930s. In the beginning, this story was made in series written in a daily Japanese newspaper which was later rearranged in a novel. The film also received many international awards including the Best Foreign Language Film in the 1956 Academy Award. The film has also been released again with the same story in the form of drama in 2014.

This article analyzed the formulas used in both fictions, including the similarities and differences, and also the factors that make them both liked according to the values and tastes of the audience. The results of the study indicate that the two action fictions generally have the same formula for characterization, narrative structure, and action motives. While the difference lies mainly in the way the author presents mythology and metaphors in it. Formula is one of the main factors that makes fiction favored and gets a positive response in the 
market, including consistency, originality, and the ability to attract miracles, settings and styles.

The research discussed about the formulas in literary works has been carried out by previous researchers, but still the object and the results obtained differ according to the research cases discussed. The first journal was written by Linda, L., \& Arianto (2018)entitled child literature genre formulation in Walt Disney animation movie. In contrast to this study, Linda examined various formulas that worked for the Disney Animation Movie specifically related to Child Literature Genre. The theory used by this study also Theory of Formula Cawelty in children's films. The results obtained in the form of children's literature in three Tangled films (2010), Brave (2012) and Frozen (2013) display formulas that are unrealistic but are presented as if they are reasonable and acceptable. This formula is intentionally built for children's stories so as to build a child's imagination relative to freedom of thought even if it presents a hyper reality.

The second journal related to the formula in literature written by Suciati (2013)an analysis of the formula towards the popularity of kite runner novels by khaled hosseini. Different from the approach have been taken by researchers. This research uses the theory of Ida in her book Fiksi Popular to analyze the tendency of the formula of the romance story in the novel The Kite Runner. The results of the research conducted that the story of Khaled Hosseini is categorized as popular literature with an indication of friendship stories formula seen from the setting, characterization and theme. Furthermore, Suciati said that the formula had an influence on the reader because it was related to the real story of the conflict in Afghanistan that made the reader want to know more about the different conditions that existed as if they were at that time and the reader could realize his desire as a solution offered by the novel.

\subsection{Synopsis of Rurouni Kenshin Stories}

The story told about a wanderer named Rurouni Kenshin was later adapted into a television series that is already famous in the world especially for lovers of Japanese anime. Himura Kenshin was a samurai who has a dark past as Hitakiri (slaughterer) Batousai. He regretted the act of murder he had done. The samurai with the characteristic of a cross-shaped wound on his left cheek decided to wander and avoid war. His wandering was apparently not without obstacles. His greatness in fighting in the past apparently made this young samurai chased by various parties ranging from the police to the mafia millionaires to use his power. However, his meeting with a guard girl Kisshin Ryu named Kamiya Kaoru during his wandering made the samurai decide not to use his katana (samurai sword) again as a killing weapon, but to protect the surrounding people. The final battle in this story was Kenshin has to fight duel with Jine Udo, a great Samurai who also masters hypnosis.Jine Udo intentionally holds Kaoru as her sacrifice so he can lure Kenshin to use his sword again to kill. The duel was finally won by Kenshin with his samurai skill and tricks (hiten mitsurugi ryu) but still kept his promise not to kill again, but paralyzed the opponent by breaking joints and muscles around his elbow so that Jine Udo could not use the Sword anymore.

\subsection{Samurai I Synopsis: Miyamoto Musashi}

Miyamoto Musashi or just called Musashi, was a samurai and Ronin that was very famous in medieval Japan. His real name was Shinmen 
Takezo. The word Musashi was another pronunciation for "Takezo". Musashi had the full name of Shinmen Musashi No Kami Fujiwara No Genshin

Miyamoto Musashi was a village boy who aspires to become a true samurai. In 1600 , which was full of turmoil, he threw himself into the Battle of Sekigahara, without realizing what he was doing. After the battle ended, he found himself lying defeated and wounded amid thousands of dead bodies. On the way home, he made a rash act that made him a fugitive until a Zen priest succeeded in conquering him. Otsu, the beautiful girl who admires him, frees Musashi from his sentence, but Musashi was caught again. After three years he must live a life of seclusion, and this period was used to explore classical Japanese and Chinese works. After being released again, he refused to be given the position of samurai. Over the next few years, he pursued his ideals with determination and following the path of the sword. He was becoming a true samurai.

The last test for him was when he had to fight Sasaki Kojiro, his toughest rival, young and strong. Musashi wanted to prove that strength and skill were not the only ones who can be relied upon to determine victory.

\section{THEORY OF THE RESEARCH}

The approach used in this analysis is the Audience Analysis approach, which is an approach used to see how cultural differences from popular fiction connoisseurs give the same or different impression on them when they enjoy a popular fiction. There are three main subject theories in popular literary research that can be used to see relationships between audiences and popular fiction, namely genres, archetypes and formulas.
In determining genre, researcher usually see the similarities of various similar stories and determine formulas that show similarities and differences so that it can be seen the type or genre. According to Kaminsky in Adi Rochani (2011) the genre helped us to see the uniqueness of individual work by making comparisons of work with other work of the same basic type. In popular fiction critics, genre theory is often touted as an important tool in criticizing it. This term usually indicates that popular forms of fiction can be identified and this identification is based on repeated forms or types that appear in the market. With this repetition, researcher can gain knowledge about the types of popular fiction and their characteristics. In this analysis, the author provided a comparison of two Japanese Samurai serial action stories that have the same elements and characteristics but differ in the time period of their publication. This will show the characteristics in the popular story of Japanese samurai in general based on the type of genre.

If the popular fiction genre can be said to be a combination of formulas in popular fiction, formula itself is the elements that characterize popular fiction both in terms of characterization, plot, flow structure, setting and theme. Cawelty (1976) defined formulas as a combination or synthesis of a number of cultural conventions that were specific to the form of universal or archetype stories. Besides Formula, another important element in popular fiction is archetypes. Archetypes are elements that can be said to be universal in popular fiction. According to Cawelty (1976)formulas and archetypes are different. Archetype is a story pattern that is not limited by a particular culture or time, while a formula is defined as a combination of cultural 
conventions that are specific between one culture and another.

Popular fiction must always have a plot that attracts attention, both the audience and the reader. Therefore, the structure of popular fiction is very dependent on the genre written. In American action stories, the main focus of the story is usually a hero whose lines are predictable. In both the Japanese samurai action stories analyzed this also has similar sequence of stories among them:

1. At the beginning of the story begins with the event of defeat that befell the hero for example in war, conflict, or crash.

2. Introducing antagonists and hero activities.

3. Hero is overwritten by problems and then becomes a "kambing hitam" / slander.

4. The Hero runs away or isolates himself, changes, and forgets his past.

5. Hero meets with the help of close friends, teachers, or usually women.

6. Hero meets with the problems faced.

7. Hero is forced to return to his past.

8. The learning outcomes of solving problems are the initial plans but this plan always fails.

9. Problem solving usually with happy ending can save the woman he desires.

\section{DISCUSSION}

Both the story of Rurouni Keshin aka Samurai X and Miyamoto Musashi are the two most famous films about martial arts in Japan. These two stories are also categorized as adventure game genre because they are more dominant in displaying abilities, techniques, and principles regarding Japanese Samurai martial arts. This categorization is also in line with Adi's Adi's statement(2011) which said that people tend to classify martial arts into a type of fight. This is due to self-defense as well as games that emphasize physical aspects and violence. Like the thing in western action films, the two fight stories also emphasize the elements of fighting knighthood, virility and agility, especially in using swords as the main weapon.

Genre labeling for popular fiction aimed for prospective viewers or readers to have an idea of what stories to read and see. In line with the statement the second genre of this story has also been clearly seen from the chosen title. Rurouni Keshin aka Samurai $\mathrm{X}$ taken from the hero name of "Samurai X" as his trademark because it has a cross-shaped scar on his face. The second story is titled Miyamoto Musashi or called by Samurai one is also taken from the name of the hero who changed his name from Takezo after he succeeded in mastering the road and the Samurai principle. Samurai one is a title that he got because his determination and toughness paralyzed many opponents with a sword. From the title, the audience will easily guess the contents of the story according to the tastes of the audience, which is related to the legendary hero with martial arts using Samurai.

Market share is the main target in the production of popular fiction. Therefore, formulas or distinctive elements as standard in popular fiction are required to be able to fulfill the intended market share tastes. Hero figure is the most important thing in the genre in action films that can answer all the desires and desires that cannot be reached by the audience. In contrast to the formula hero in western films that are more closely related to their physical appearance, in the Asian action film they show more agility and tricks as martial arts actors. As Adi (2011)mentions the superiority of the main characters in the Chinese and Indonesian action 
films more often shown by moving agility (inward force) and inward power. In both of these films, the chosen character has a relatively small physical body and does not show off muscles, this is also in accordance with the posture of the Asian community in general. This is highlighted in the film through his speed and activity in swinging swords. Like the hero of Musashi, He is also famous for his sword techniques created Nitouryu the technique of fighting with two swords and the ability to knock out an opponent with one deadly movement. Whereas Kenshin is famous for his sword style hiten mitsurugi ryu, bottou-jutsu, sou ryu sen with his lightning speed.Besides showing its agility, good looks are also a major factor in the selection of hero actors. The character Kenshin is played by Takeru Sato, whose figure that famous through the film Kamen Rider Den O. The market share that is glimpsed in this film is of course men of all ages, especially in Asia who crave ideal figures like Takeru Sato.

Another factor that caused these two films to be so popular is the formula found in the personality and character of the hero that is highlighted. Samurai in Japan are famous for their toughness, cruelty, and killing ambitions to knock out opponents. Since the 17th century, samurai are famous for the teachings of bushido. Consisting of three kanji, bu (war), shi (person), do (road), this teaching seems to confirm that the path of a samurai is on the battlefield and serves someone(Stanton, 2007).Whereas no-man's samurai is also called a ronin whose life is neglected and supports himself by disturbing others. Whereas a no-man's samurai is also called a ronin whose life is neglected and supports himself by disturbing others. The second hero of the film is the antithesis of the samurai legend in general, Miyamoto Musashi prefers to wander and learn sword techniques rather than serving his master. He also prefers to knock out his opponent with his wooden sword when dueling with an opponent without having to kill him.

Like other action stories, rationality in action films is sometimes marginalized. Popular fictional culture in action films prioritizes entertainment in battles and fights. The heroine is a deity figure who cannot be defeated even though he is already in a tight squeeze and with minimal weapons(Swirski, 1999).In the story of Miyamoto Musashi, heroes often face very many opponents of more than 100 ronin with their own hands, the hero in this story is also told to be able to compete 60 duel challenging famous and great warriors with wooden swords without being defeated. The story of Rurouni Kenshin also depicts a hero who is able to cripple tens of opponents using only an inverted blade, but all these irrational actions can be packaged through his speed and greatness in using sword techniques. That is, a culture becomes popular because it contains elements of entertainment that are liked by many people and easily understood by everyone and the idea of its creation is intended to get the greatest benefit. In other words, the cause of a culture can be popular with regard to the first three things that are easily understood by everyone, both are liked by many people and the third is making money.

Regarding the target market in action films, namely men and teenagers and adults, the film also highlights its masculinity by involving women as supporting actors. Besides the heroic character and character of the hero that was created there were always women who became supporters behind his greatness. Even for the fulfillment of the audience's appetite for hero 
figures, the author deliberately builds an element of romance in the story with women as mastermind behind the problem so the hero must save him. In the film Miyamoto Musashi, a female figure is seen from Otsu, a beautiful girl who admires her. In his wanderings, Musashi is described as having always had difficulty in meeting Otsu, because there is another figure named Grandma Osugi who always obstructs their meetings. Female figure is portrayed through the figure of Kamiya Kaoru who always reminds Kenshin when he wants to violate his oath not to kill. Unlike the previous film, the figure of Kaoru in this story is always involved in problems faced by heroes and poses a threat to the hero character to get out of the principle he holds. Like the romance spices in other action films, various problems faced by heroes can be overcome by their ability to use swords and always end with a happy ending.

In addition, the antagonist role also has a certain formula. Of course the formula that appears in the antagonist figure must be contrary to the character and character possessed by the Hero. It is intended that whatever the hero does to the role of the antagonist can be accepted by the reader even though it is in the form of treatment in the form of violence. As Adi (2011) said that there are five formulas that appear in the antagonist figure:

1. Criminals pursue wealth and power

2. Natural forces or non-human beings that threaten human safety

3. Terrorists who fight for an ideology

4. Individuals who take revenge

5. Chaos due to changes in values in society.

In both of these stories, the antagonist has

a different formula motif. Musashi's film introduces several antagonistic roles originating from several colleges challenged by the hero. However, in general the character displayed on the antagonist is always the opposite, for example the character Seijuro, the leader of the Yoshioka college, has an arrogant character, likes to play girls, and Toji is also a teacher from Yashioka after losing to face Musashi to flee and become a robber. Furthermore, the figure of Kizaemon, the Yagyu Seikushai style teacher from Koyagyu Castle has a large, cruel and merciless body. The last is Sasaki Kojiro, Musashi's toughest opponent who has a good, positive, agile, and handsome character. The last antagonist figure that was created was his assumption that the reader would be more lulled that the most appropriate enemy to face the hero must be balanced with him, by defeating a balanced enemy the hero could increasingly show his greatness.

The story of Rurouni Kenshin, the antagonist figure is in the figures of Takeda Kanryu and Jine Udo. Kanryu is portrayed as a wealthy person, recruiting many Ronin as men to launch his business, corruptors who bribe the police, and the opium dealer (a type of narcotics). This formula was formed also related to the target market of men, the middle and lower classes, and the working class. Those who in fact often feel direct economic difficulties will support the hero to crack down on the antagonist characters who are described as common enemies. The second antagonist named Jine Udo, the motive is different from before. Udo is a wandering samurai who is also not ambitious about the world. His motives are only to get prestige defeating the legendary samurai batosai. This opponent became Kenshin's duel at the end of the story. 
As explained earlier that popular fiction is a means to gain profits and bring in money, the producer deliberately makes several strategy formulas on an ongoing basis, especially to release the next film episode. This formula is evident in the big screen films that emerged in the 20th century. At the end of the story, the film aired intentionally floats and often introduces a new antagonist who suddenly appears before the film ends. It also appears in western and Asian films such as fast and furious 7 (2014), Guardians of galaxy (2014), the raid (2013), despicable (2010), etc. In the film Rurouni Kenshin After being able to defeat the duel against Jine Udo, the introduction of the new antagonist Shishio Makoto appears. Shishio has the ability and background of the past with the hero, except that he turned into an opponent of the government because he was betrayed after his dedication to being the government's previous elite samurai force. After successfully gaining profits reaching 36.7 million dollars in Japan and 25 million dollars internationally, the producer released the film at the end of 2014 under the title Rurouni Kenshin: Kyoto Inferno (IMDb, 2014).

\section{CONCLUSION}

The story of Rurouni Keshin aka Samurai X and Miyamoto Mushasi are two genre stories of martial arts matches with the hallmark of using the most famous samurai in Japan. These two stories became very popular because of their ability to build formulas that were adjusted to the target market, namely men, adults and the elderly, the middle and lower classes, and the working class. Hero is the dominant factor highlighted in this action film. Hero was created as a reflection of the ideal imaging desire expected by the audience, so that the audience jumped in and supported all the actions taken by the hero. While the formula formed on the antagonist opposes the life of the audience so that it is natural to be conquered. As for the formation of popular culture, popular fiction also aims to gain maximum profit. So that the formula formed must be in accordance with the tastes and values that exist in the intended market share.

\section{REFERENCE}

Adi Rochani, I. (2011). Fiksi populer: Teori dan metode kajian. Yogyakarta: Pustaka Pelajar.

Cawelty, J. G. (1976). Adventure, Mystery, and Romance. Chicago: University of Chicago Press.

Faruk, \& Suminto, A. S. (1997). Sastra Populer. Jakarta: Universitas Terbuka.

Ibrahim, I. S. (1997). Lifestyle Ecstasy: Kebudayaan dalam Masyarakat Komoditas Indonesia. Yogyakaarta: Jalasutra.

IMDb. (2014). Rurouni kenshin part II: Kyoto inferno (2014) Rurôni kenshin: Kyôto taika-hen (original title). Retrieved from https://www.imdb.com/title/tt3029558/?re $\mathrm{f}_{-}=\mathrm{nv} \_\mathrm{sr} \_1$

Kayam, U. (1981). Seni, Tradisi, Masyarakat (essays) (in Indonesian). Jakarta: Penerbit Sinar Harapan.

Linda, L., \& Arianto, T. (2018). Child literature Genre Formulation in Walt Disney Animation Movie. Jurnal BASIS, 5(2), 1120.

https://doi.org/https://doi.org/10.33884/bas isupb.v5i2.776

Stanton, R. (2007). Teori Fiksi Robert Stanton. Diterjemahkan oleh Sugihartuti dan Rossi Abi Al Irsyad. Yogyakarta: Pustaka Pelajar.

Suciati, E. (2013). Analisis formula Terhadap Popularitas Novel the Kite Runner Karya Khaled Hosseini an Analysis of Formula towards the Popularity. DIGLOSSIA, 6(2), 78-90.

https://doi.org/https://doi.org/10.26594/dig 
lossia.v6i2.387

Swirski, P. (1999). Popular and Highbrow Literature: A Comparative View. Purdue University Press, 1(4), 36-46. Retrieved from

http://docs.lib.purdue.edu/clcweb/voll/iss $4 / 4$

Victor E. Neuburg. (1977). Popular Literature: A History and Guide, from the Beginning of Printing to the Year 1897. London: Woburn Press. 
DOI: 10.33884/basisupb.v6i1

e-ISSN. 2406 - 9809 p-ISSN. 2527 - 8835
Jurnal Basis Vol. 6 No.l April 20IG

English Department - Putera Batam University

64 | P a g e 